\title{
Attachment and Parental Practices as Predictors of Behavioral Disorders in Boys and Girls ${ }^{1}$
}

\author{
Sandra Adriana Neves Nunes ${ }^{2}$ \\ Faculdade de Ilhéus, Ilhéus-BA, Brazil \\ Ana Maria Xavier Faraco \\ Mauro Luis Vieira \\ Universidade Federal de Santa Catarina, Florianópolis-SC, Brazil
}

\begin{abstract}
This study's objective was to investigate how two parental systems (attachment and parental practices) interact to predict internalizing and externalizing behavioral problems in girls and boys. The Security Scale was administered to 289 children (mean age $=10.5$ years), and 205 parents completed the Child Behavior Checklist and an instrument addressing parental practices. The results indicate that poor maternal attachment predicts aggression and delinquency in boys, while problems of this nature among girls are predicted by parental rejection and low behavioral control. Poor paternal attachment was the only predictor for social withdrawal and anxiety/depression in boys. A tendency of association between poor maternal attachment and social withdrawal was observed among girls, while low behavioral control and high psychological control predicted anxiety/depression. The results are discussed in terms of their contribution to understanding the complex relationship among gender, parental systems, and behavioral disorders.
\end{abstract}

Keywords: gender, attachment behavior, behavior disorders, parental practices

\section{Apego e Práticas Parentais Como Preditores de Distúrbios de Comportamento em Meninos e Meninas}

Resumo: O presente estudo teve como objetivo investigar de que forma dois sistemas parentais (sistema de apego e sistema de práticas parentais) se relacionam para predizer os problemas de externalização e de internalização em meninos e meninas. No total, 289 crianças (idade média $=10,5$ anos) responderam à Escala de Segurança e 205 cuidadores responderam a um instrumento sobre práticas parentais e ao Child Behavior Checklist. Os resultados indicaram que para meninos, vínculo de apego materno frágil prediz agressividade e delinquência. Para meninas, problemas dessa natureza são preditos por rejeição parental e pouco controle comportamental. Apego paterno frágil foi o único preditor de retraimento social e ansiedade/depressão em meninos. Entre as meninas, constatou-se uma tendência de associação entre apego materno frágil e retraimento social, enquanto baixo controle comportamental e alto controle psicológico predisseram ansiedade/depressão. Os resultados são discutidos em termos de sua contribuição para o entendimento da complexa relação entre gênero, parentalidade e problemas comportamentais.

Palavras-chave: gênero, comportamento de apego, distúrbios do comportamento, práticas parentais

\section{Apego y Prácticas Parentales Como Predictores de los Trastornos del Comportamiento en Niños y Niñas}

\begin{abstract}
Resumen: El presente estudio tuvo como objetivo investigar cómo los sistemas parentales (sistema de apego y sistema de prácticas parentales) se relacionan para predecir los problemas de externalización e internalización en niños y niñas. Los niños $(n=289$, edad media $=10,5$ años) respondieron a la Escala de Seguridad y 205 padres respondieron a un cuestionario sobre las prácticas educativas y la Child Behavior Checklist. Los resultados indican que, para los niños, apego materno frágil predice agresión y delincuencia. Para las niñas, estos problemas se predicen por rechazo parental y bajo control del comportamiento. Apego paternal frágil fue el único predictor de aislamiento social y ansiedad/depresión en los niños. Entre las chicas, hubo una tendencia de asociación entre apego materno frágil y aislamiento social, mientras que bajo control del comportamiento y alto control psicológico predijeron ansiedad/depresión. Los resultados se discuten en términos de su contribución a la comprensión de la compleja relación entre género, parentalidad y problemas de comportamiento.
\end{abstract}

Palabras clave: género, conducta de apego, trastornos de la conducta, prácticas parentales

\footnotetext{
${ }^{1}$ Paper derived from the first author's doctoral dissertation under the advisory of the third author and co-advised by second author defended in 2012 for the Graduate Program in Psychology at the Universidade Federal de Santa Catarina. Acknowledgment: the authors thank the schools' pedagogical teams, the teachers, children and their parents who generously participated in the study. The authors also thank Professor Carolina Saraiva de Macedo Lisboa, of the Universidade do Vale do Rio dos Sinos (UNISINOS), for her help during data collection. Support: National Council for Technological and Scientific Development (CNPq) and Coordination for the Improvement of Higher Education Personnel (CAPES).

2 Correspondence address:

Sandra Adriana Neves Nunes. Faculdade de Ilhéus. Rodovia IlhéusOlivença, km 2,5. CEP 45650-000. Ilhéus-BA, Brazil. E-mail: psandranunes7@hotmail.com
}

Researchers addressing Developmental Psychopathology have sought to understand the factors that trigger and impact the developmental course of externalizing and internalizing problems. The concept of externalizing problems refers to a set of behavioral and psychological signs that are statistically associated with aggressiveness, delinquency, impulsiveness and hyperactivity and are based on one's low ability to control impulses. The set of internalizing problems, on the other hand, encompasses an excessive control of impulses associated with anxiety, depression, social withdrawal and somatic complaints 
(Achenbach \& Eldelbrock, 1978). There is evidence that the quality of relational systems between parents and children - attachment and parental practices - can clarify behavioral problems during childhood (Rubin, Coplan, \& Bowker, 2009).

Attachment, constructed on a behavioral system of interactions between caregiver/child, was philogenetically developed to increase the chances of children surviving. This system enables the development of a long-lasting affective attachment (bonding) between the caregiver and infant and its activation occurs as a result of physiological stressors or potential danger, and in the face of unavailability of the attachment figure. Responsive and sensitive mothers tend to develop a secure attachment system with their infants. Secure attachment provides the child with an internal working model (IWM) that is the base for exploring the world and establishing relationships with others.

The IWM is updated over the course of development due to the new relationships the child establishes, but the parental figures continue to play a secure and supportive role for children in mid-childhood, approximately between the ages of seven and 12 (Kerns, Aspelmeier, Gentzler, \& Grabill, 2001). In this stage of development, the perception of the caregiver's availability is the primary purpose of attachment (Kerns, Keplac, \& Cole, 1996). Additionally, the quality of attachment is implicated in the adaptation of individuals over the course of their development. For instance, in terms of externalization problems, the meta-analysis studies (Fearon, Bakermans-Kranenburg, van IJzendoorn, Lapsley, \& Roisman, 2010) show evidence of a positive association between insecure attachment and externalizing problems of low to moderate magnitude. Regarding internalizing problems, longitudinal research has confirmed an association between poor attachment and anxiety (Van Brakel, Muris, Bogels, \& Thomassen, 2006). Association between insecure attachment and depression was also confirmed in a study conducted by Graham and Easterbrooks (2000), while there is also evidence that insecure attachment is more common than secure attachment in socially withdrawn children (Rubin et al., 2009).

In addition to the quality of attachment, parental practices seem to play an important role in the genesis and manifestation of externalizing and internalizing problems. Among the parental practices that most affect a child's socioemotional adjustment, parental rejection (Rohner \& Britner, 2002), behavioral control, and psychological control (Barber, 1996; Laird, Marrero, \& Sentse, 2010) stand out. Parental rejection is defined in terms of a lack of or withdrawal of parental affection and has negative implications for children (Rohner \& Britner, 2002). On the other hand, behavioral control meets the children's need of support and guidance and, therefore, has positive implications for child development (Barber, 1996). Finally, because psychological control hinders the children's psychological autonomy, it negatively affects one's emotional adjustment (Barber, 1996; Karreman, van Tuijl, van Aken, \& Dekovíc, 2010).
A revision study conducted by Rohner and Britner (2002) found evidence that parental rejection is associated with internalizing problems, especially depression and depressive mood in the United States, China, Australia, Germany, Italy, Egypt, Spain, Switzerland, and Turkey. Finally, parental rejection was also associated with anxiety (Roelofs, Meesters, Ter Huurne, Bamelis, \& Muris, 2006). Besides being associated with internalizing problems, parental rejection is also a predictor of externalizing problems, including delinquency, behavioral disorders and the abuse of illegal substances (Rohner \& Britner, 2002). The authors have also reported vast evidence of this association, including in the United States, China, Croatia, England, Finland, India, Japan, Norway and Pakistan.

Behavioral control, in turn, is negatively related to externalizing problems like antisocial and behavioral disorders in children (Barber, 1996; Laird et al., 2010) and delinquency and aggressiveness in adolescents (Finkenauer, Engels, \& Baumeister, 2005). Furthermore, psychological control is directly associated with internalizing problems (Barber, 1996; Finkenauer et al., 2005 ) including social withdrawal in childhood (Rubin et al., 2009), but there is also evidence that psychological control is associated with externalizing problems (Barber, 1996; Finkenauer et al., 2005).

Moreover, various researchers have suggested that boys present more externalizing problems than girls (Burt, Mikolajewski, \& Larson, 2009; Prinzie, Onghena, \& Hellinckx, 2006), indicating that gender differences are an important factor to be taken into account in the predictive analysis of externalizing and internalizing problems. In Brazil, Bandeira, Rocha, Souza, Del Prette and Del Prette (2006) and Graminha (1994) also found evidence that boys exhibit this behavioral problem more frequently than girls. There are, however, studies showing that the differences observed are not significant (Marturano, Toller, \& Elias 2005; Saud \& Tonelotto, 2005).

In regard to girls, the literature suggests that they are more likely to develop internalizing problems (Muris, Meesters, \& van den Berg, 2003) and this tendency was also observed in Brazil (Saud \&Tonelotto, 2005). Finally, Cassidy (1994) suggests that boys more frequently establish secure attachments with fathers and girls with mothers (same-sex linkage hypothesis). This hypothesis was entirely confirmed by Diener, Isabella, Behunin, and Wong (2008), partially confirmed by Liu (2008) and not verified by BoothLaforce et al. (2006) or Lieberman, Doyle, and Markiewicz (1999). Such a controversy among the results may arise from the way boys and girls perceive the instruction they received from their fathers and mothers (Muris et al., 2003; Roelofs et al., 2006; Teixeira, Oliveira, \& Wottrich, 2006).

More recent studies (Muris et al., 2003; Nishikawa, Sundbom, \& Hägglöf, 2010; Roelofs et al., 2006) investigated, separately, boys and girls in the way attachment and parental practices are combined to predict socio-emotional 
adjustment during childhood. Muris et al. (2003) concluded that, regardless the child's gender, insecure attachment and parental practices play an unique role in the prediction of internalizing problems. Nonetheless, only parental practices (affection, rejection, and overprotection) have predictive value concerning externalizing problems.

Roelofs et al. (2006), in turn, concluded that only negative maternal practices explain externalizing and internalizing problems among girls, while paternal rejection explained aggressiveness among boys. Depression among boys is also predicted by insecure attachment with the father, paternal rejection and educational practices impregnated with anxiety. Finally, anxiety was predicted by insecure attachment and maternal rejection.

Nishikawa et al. (2010) concluded that, for boys, the model that included insecure attachment (ambivalent), parental rejection (from mother and father), and instruction permeated by anxiety (mother and father), were among the better predictors of externalizing disorders while insecure attachment (ambivalent and avoidant), parental rejection (from both mother and father) and paternal overprotection are predictors of internalizing problems. For girls, all the dysfunctional parental practices (rejection, overprotection and an anxious disposition in raising a child, by both parents) are associated with ambivalent insecure attachment, predicting internalizing problems, while parental practices such as rejection, overprotection, anxious disposition while raising a child (on the part of both mother and father) and paternal emotional warmth predicted externalizing problems.

Even though there is a predictive role that parental practices and quality of attachment play in relation to internalizing and externalizing problems, when the results are controlled by gender, some variations emerge. These variations may be related to the social and cultural environmental conditions where data were collected. Hence, this study's objective was to investigate how these two parental systems (attachment system and parental practices system) interact to predict externalizing and internalizing problems in boys and girls aged between 9 and 13 years old. Our hypothesis is that negative parental practices will better predict both externalizing and internalizing behavioral disorders among girls. In general, the results are less clear for boys; they indicate that attachment is the primary predictor, while parental practices are a secondary predictor of internalizing disorders.

\section{Method}

\section{Participants}

A total of 289 , grade 4 children ( $48.2 \%$ of girls, mean age $=10.5$ years old; $S D=.77$ ) from four public schools (two in each city) in the Southern area of Brazil, along with 205 caregivers, participated in the study. Mothers were 37.28 years old on average $(S D=7.06)$ and fathers were 41.13 years old on average $(S D=7.92)$. Most mothers $(84.4 \%)$ and fathers $(82.4 \%)$ had completed either middle school or high school and $52.8 \%$ of mothers and $79.1 \%$ of fathers were regularly employed.

\section{Instruments}

Because this study is directly linked to an international research project that uses the same measures properly adapted to the different partners countries, the instruments in English were translated and adapted to Portuguese by professionals fluent in both languages. Another three experts independently performed the back-translations. These experts were referred to by the research group titled "Friendship relationships in Childhood, Parental influences and Ecological transitions in the Southern region of Brazil", financially supported by contract MCT/CNPq (Protocol No. 014/2008, process No. $477218 / 20083$ ), to which this study is linked.

Data were derived from the following instruments:

Security Scale by Kerns et al. (1996): used to assess the quality of attachment. The scale is composed of 15 items for the mother $(\alpha=.74)$ and the same 15 items for the father $(\alpha=.81)$. The internal consistency indexes reported for this scale originated from analyses conducted with this study's sample. The scales assess the dimensions "availability and responsiveness of mother and father" and "ease of communication and support, from both parents, in times of stress". Each item presents two statements linked by the conjunction "however." For instance, "Some children find it easy to count on their mothers for help, however, other children find it difficult to count on their mothers when they need to". The child should first choose the statement that would best describe her/him and then indicate the level of agreement $(1=$ sort of true and $2=$ really true $)$ with the statement chosen. The Security Scale has not yet been validated for the Brazilian culture using Confirmatory Factor Analysis (CFA).

Child-Rearing Practices Report Questionnaire (CRPR) reviewed by Rickel and Biasatti (1982): this measure was used to address the dimensions of parental practices. The CRPR is composed of 42 items on a six-points Likert $(1=$ strongly disagree and $6=$ strongly agree). Based on Exploratory Factor Analyses with varimax rotation, two factors were initially extracted: rejection and control. The factor rejection was composed of tree items $(\alpha=.69)$ incorporating questions that denoted disappointment, hostility and conflictive interaction between parents and children. For instance: "I feel a little disappointed with my child". The Control factor revealed two dimensions in subsequent analyses: behavioral control with 14 items $(\alpha=.70)$, which show the way parents regulate the behavior of their children, through plausible demands of maturity and monitoring (e.g. "I keep myself informed about where my child is and what $\mathrm{s} / \mathrm{he}$ is doing") and psychological control with 13 items $(\alpha=.69)$, marked by parental intrusiveness, inducing guilt and anxiety (e.g. "I believe my child has to be aware of how much I sacrifice myself for him"). The internal consistency indexes reported for this scale were also derived from analyses conducted 
with this study sample. This scale has not yet being validated through CFA in Brazil.

Child Behavior Checklist 4-18 years (CBCL) (Achenbach, 1991): in this measure, two subscales were specifically employed for externalizing problems: (a) aggressiveness with 21 items ( $\alpha$ $=.90$ ), which describes openly aggressive behavior; and (b) delinquency $(\alpha=.83)$ with 15 items, which addresses behaviors that violate legal or moral rules. For the internalization problems the following subscales were used: (a) social withdrawal with 10 items $(\alpha=.75)$, which describes social isolation, shyness, and social difficulty with peers; and (b) anxiety/depression $(\alpha=.82)$ with 18 items addressing depressive behavior and generalized anxiety. The internal consistency indexes reported for these scales concern the translated version. The CBCL was submitted to criteria validation by Bordin, Mari and Caeiro (1995) in Brazil. Its Brazilian version achieved good sensitivity (87\%), correctly identifying $75 \%$ of mild cases, $95 \%$ of moderate cases and $100 \%$ of the severe cases.

\section{Procedure}

Data collection. Data were collected in two cities in the Southern area of Brazil. The researchers for the project met with the school principals and pedagogical coordinators in the first semester of 2009 to clarify the study proposal and obtain their written consent. Mothers, fathers (or caregivers in the absence of parents) and teachers from each school were invited to participate in a meeting with the researchers who presented and explained the study's objectives and the conditions in which it would occur. Data collection was conducted with all the children attending $4^{\text {th }}$ grade in their own classrooms, while caregivers answered the instruments in groups or individually in a school room or wherever they found more convenient. At least three researchers monitored the children during the administration of the questionnaires and were available to clarify doubts that the children may have had. All the situations that deserved special attention were registered in a field diary. Sample loss was $5.95 \%$ $(n=17)$ of children whose caregivers did not authorize their participation in the study and $24.1 \%(n=70)$ of caregivers, either because they did not attend the meeting or did not return a completed questionnaire.

Data analysis. Data analysis involved descriptive statistics (mean, standard deviation, asymmetry and kurtosis) and inferential analysis (independent $t$ test and Multiple Regression Analysis). SPSS version 17.0 was used for all the statistical procedures.

\section{Ethical Considerations}

This study was approved by the Institutional Review Board at the University of Vale do Rio dos Sinos (UNISINOS) (Report 038/2009) on May 29, 2009. Only the adults who freely signed informed consent forms and the children whose caregivers gave them a written consent form, participated in the study.

\section{Results}

\section{Group Differences: Gender, Behavioral Problems, Attachment and Parental Practices}

Table 1 presents the results concerning the means and standard deviations of all the variables for girls and boys.

In regard to the studied behavioral problems, boys presented a higher mean for aggressiveness, $t(180)=2.56$; $p=.011$. The size of the effect associate with the existing difference was from small to medium $(d=.38)$. In regard

Table 1

Comparisons of Averages and Standard Deviations of Variables for Girls and Boys

\begin{tabular}{|c|c|c|c|c|c|}
\hline & \multicolumn{2}{|c|}{ Girls } & \multicolumn{2}{|c|}{ Boys } & \multirow{2}{*}{$p$-value } \\
\hline & $\mathrm{M}$ & DP & $\mathrm{M}$ & DP & \\
\hline $\begin{array}{l}\text { Maternal } \\
\text { Attachment }\end{array}$ & 3.25 & 0.53 & 3.17 & 0.53 & .200 \\
\hline $\begin{array}{l}\text { Paternal } \\
\text { Attachment }\end{array}$ & 2.97 & 0.61 & 2.98 & 0.56 & .955 \\
\hline Rejection & 2.65 & 1.35 & 2.92 & 1.49 & .167 \\
\hline Behavioral Control & 5.19 & 0.53 & 5.09 & 0.59 & .172 \\
\hline $\begin{array}{l}\text { Psychological } \\
\text { Control }\end{array}$ & 4.15 & 0.77 & 4.02 & 0.74 & .130 \\
\hline Aggression & 0.42 & 0.33 & 0.56 & 0.3 & $.011 *$ \\
\hline Delinquency & 0.13 & 0.12 & 0.18 & 0.17 & $.053 \dagger$ \\
\hline Social Withdrawal & 0.26 & 0.24 & 0.31 & 0.27 & .151 \\
\hline $\begin{array}{l}\text { Anxiety/ } \\
\text { Depression }\end{array}$ & 0.37 & 0.26 & 0.40 & 0.30 & .472 \\
\hline
\end{tabular}

to delinquency, we observed that the differences of means were marginally significant $t(185)=1.95 ; p=.053$. No other significant difference was found between boys and girls for the remaining variables.

\section{Predictive Models of Behavioral Problems for Boys and Girls}

Based on theoretical and empirical evidence that girls and boys differ not only in terms of the incidence of externalizing and internalizing problems but also in terms of the factors associated with each of these problems, we decided to investigate whether the regression model would reveal particularities for the genders for all the behavioral problems under study. The results in which the regression coefficients are significant are presented in Table 2.

Table 2 shows that aggressiveness in boys was predicted by poor maternal attachment $F(1,79)=5.29 ; p=.024$, explaining $6.3 \%$ of the variance in this dimension. In girls, aggressiveness was predicted by the variables related to parental practices, specifically high levels of parental rejection and low levels of behavioral control $F(2,75)=4.64 ; p=.013$, together explaining $11 \%$ of the variance. 
A very similar phenomenon occurred in relation to delinquency. The quality of attachment in relation to the mother was the best predictor of delinquency $(\beta=-.21)$

Table 2

Stepwise Regression Predicting Aggressiveness, Social Anxiety/ Depression Predictor Variables Among Boys and Girls

\begin{tabular}{|c|c|c|c|c|}
\hline & \multicolumn{2}{|c|}{ Boys } & \multicolumn{2}{|c|}{ Girls } \\
\hline & $\mathrm{B}$ & $\beta$ & $\mathrm{B}$ & $\beta$ \\
\hline \multicolumn{5}{|l|}{ Aggression } \\
\hline Constant B & $1.18^{* * *}$ & & $.92 *$ & \\
\hline$(\mathrm{SE})$ & $(.27)$ & & $(.37)$ & \\
\hline Maternal Attachment & $-.19 *$ & $-.25^{*}$ & & \\
\hline Rejection & & & $.06^{*}$ & $.25^{*}$ \\
\hline $\mathrm{F}$ & $5.29 *$ & & $4.64 *$ & \\
\hline $\mathrm{R}^{2}$ & .63 & & .110 & \\
\hline \multicolumn{5}{|l|}{ Delinquency } \\
\hline Constant B & $.35 * * *$ & & $.32 *$ & \\
\hline$(\mathrm{SE})$ & $(.13)$ & & $(.13)$ & \\
\hline Maternal Attachment & $-.07 *$ & $-.21 *$ & & \\
\hline Rejection & $.02 \dagger$ & $.18 \dagger$ & $.03 * *$ & $.33 * *$ \\
\hline Behavioral Control & & & $-.05^{*}$ & $-.22 *$ \\
\hline $\mathrm{F}$ & $4.05^{*}$ & & $7.84 * *$ & \\
\hline $\mathrm{R}^{2}$ & .091 & & .167 & \\
\hline \multicolumn{5}{|l|}{ Social Withdrawn } \\
\hline Constant B & $.76^{*}$ & & $.54 * *$ & \\
\hline$(\mathrm{SE})$ & $(.15)$ & & $(.16)$ & \\
\hline Maternal Attachment & & & $-.09 \dagger$ & $-.19 \dagger$ \\
\hline Paternal Attachment & $-.15^{* *}$ & $-.31 * *$ & & \\
\hline $\mathrm{F}$ & $8.64 * *$ & & $3.09 \dagger$ & \\
\hline $\mathrm{R}^{2}$ & .086 & & .038 & \\
\hline \multicolumn{5}{|l|}{ Anxiety/Depression } \\
\hline Constant B & $.86^{* * *}$ & & $.58 *$ & \\
\hline$(\mathrm{SE})$ & $(.18)$ & & $(.29)$ & \\
\hline Paternal Attachment & $-.15^{*}$ & $-.29 *$ & & \\
\hline Behavioral Control & & & $-.11 *$ & $-.23 *$ \\
\hline Psychological Control & & & $.09 *$ & $.26^{*}$ \\
\hline $\mathrm{F}$ & $6.94 *$ & & $3.95 *$ & \\
\hline $\mathrm{R}^{2}$ & .085 & & .069 & \\
\hline
\end{tabular}

among boys, although parental rejection also shows a tendency of association $(\beta=.18)$. Both variables together explain $9.1 \%$ of the variance of delinquency among boys, $F$ $(2,81)=4.05 ; p=.021$. Again, for the girls, parental rejection and behavioral control were predictors of delinquency, $F(2,75)=7.84 ; p=.001$. This predictor model explained almost $17 \%$ of the variance in delinquency among girls.

Concerning the prediction of internalizing problems among boys, paternal attachment was the only predictor of social withdrawal, $F(1,75)=8.64 ; p=.004$, explaining $8.6 \%$ of variance. The prediction model for social withdrawal among girls, in turn, was only marginally significant
$F(1,79)=3.09 ; p=.08$, while only the variable maternal attachment presented a trend of negative association with the criterion variable (social withdrawal).

In the prediction of anxiety/depression, quality of attachment in relation to the father was the only variable that predicted these internalizing problems among boys $F(1,75)=6.94 ; p=.010$, explaining $8.5 \%$ of the variance. On the other hand, psychological control and behavioral control were predictors of anxiety/depression $F(2,78)=3.95$; $p=.023$ among girls and together explained slightly more than $9 \%$ of the variance.

In summary, the results indicate that, for boys, poor maternal attachment predicts externalizing problems and poor paternal attachment predicts internalizing problems. For the girls, the variables that predicted both externalizing and internalizing problems were parental practices.

\section{Discussion}

This study was grounded on several premises: first, we assumed, based on the literature, that there would be gender differences for externalizing and internalizing problems. We also assumed that the child's gender would have some effect on the manner parents raised their children. Less theoretical agreement was found for gender differences in relation to quality of parental attachment and, for this reason, no hypothesis was proposed at the beginning. In relation to the predictive hypotheses, we assumed that negative parental practices would be better predictors of behavioral problems for girls. For the boys, attachment would contribute more, possibly followed by parental practices, to predicting the children's behavioral problems.

\section{Children's Gender and Externalizing Problems}

Boys were assessed by their caregivers as being more aggressive than girls, confirming the findings of various international studies (Burt et al., 2009; Prinzie et al., 2006). Two Brazilian studies, however, (Marturano et al., 2005; Saud \& Tonelotto, 2005) which also employed the CBC scales, do not confirm this tendency. Such a divergence in the results may be associated with the samples' characteristics. Data obtained by Marturano et al. (2005) derive from a clinical sample composed of children with poor school performance, a characteristic that has been related to behavioral problems, regardless of the child's gender. The reduced sample size used by Saud and Tonelotto (2005) $(n=41)$ may have interfered in the results.

Rigorously considering the cut-off point of $p \leq .05$, the boys and girls in this study presented similar scores for delinquency. The reasons explaining the existence of gender differences for aggressiveness, but not for delinquency, may be based on biology and cultural environment of development. The findings Burt (2009) reported in a meta-analysis study show strong evidence that genetics contributes more to 
explaining aggressive behaviors, while the influence of social environment would explain delinquency better.

Hence, because delinquency occurs more due to socio-environmental factors than biological ones, children, regardless of gender, who are subject to similar environments during their development (e.g. an environment marked by hostility and rejection) are more likely to present identical scores for delinquency (Moffit \& Caspi, 2001).

\section{Children's Gender and Internalizing Problems}

In regard to internalizing problems, no significant differences were found for depression/anxiety in terms of gender differences. Similar levels of depression/anxiety among gender are in contrast with the findings of studies indicating that girls tend to be more depressive and anxious (Marturano et al., 2005; Muris et al., 2003; Saud \& Tonelotto, 2005). It is possible that the disparity of findings is explained by the ages studied. According to Côté, Tremblay, Nagin, Zoccolillo, and Vitaro (2002), differences concerning internalizing symptoms in girls, especially signs of anxiety, tend to emerge from the ages of 13 and 14, an age group that was not included in this study. Finally, as expected, regardless of gender, signs of social withdrawal seem to be expressed in similar ways among children, as already suggested by Rubin et al. (2009).

\section{Children's Gender and Attachment}

Analyses testing the hypothesis of gender identity in terms of attachment (same-sex linkage hypothesis), which suggests that girls are more connected to mothers than boys and boys are more connected to fathers than girls (Cassidy, 1994), show opposite results. In accordance with the findings of Booth-Laforce et al. (2006) and Lieberman et al. (1999), boys and girls reported being equally connected to both mothers and fathers. These findings indicate that fathers, as much as mothers, are capable of providing support and being available to listen to their children in times of stress, regardless of a child's gender. There has been in recent years an increase in the quality of paternal participation in the involvement and care provided to children to the point that the paternal figure has become indispensable to the development of various psychological functions of children.

\section{Children's Gender and Parental Practices}

No significant difference was found in regard to parental practices for boys and girls. In contrast with the results found by other researchers (Finkenaueret al., 2005; Roelofs et al., 2006), the psychological control exerted by caregivers did not present differences between boys and girls in this study. The scores concerning behavioral control were similar for both genders, which differ from what Finkenauer et al. (2005) and Teixeira et al. (2006) suggest. Finally, the levels of rejection reported by the parents did not significantly differ among genders, in contrast with what Roelofs et al. (2006) suggested.
These disparate results may have an important methodological explanation. The parental styles in all the mentioned studies were reported by the children themselves, while in this study, the caregivers were the ones who provided information regarding levels of rejection and parental control. It is possible that if the children had provided information concerning parental bearing practices, they would have assessed them differently depending on their gender.

\section{Differences Between the Predictive Models for Aggressiveness, Delinquency, Social Withdrawal and Anxiety/Depression for Boys and Girls}

The results show specificities of gender for the regression models that sought to predict externalizing (aggressiveness and delinquency) and internalizing problems (social withdrawal and anxiety/depression). For boys, an increase in the levels of aggressiveness and delinquency was explained by the perception that the mother is seldom available, responsive or open to communication and offers little support in times of stress. Such a perception of attachment seems not to impact externalizing problems in the case of girls. In fact, it is the quality of parental practices reported by the caregivers themselves (in this case, rejection and behavioral control) that seem to contribute to the occurrence of problems of this nature among girls. These results partially confirm this study's primary hypotheses. Similar conclusions were obtained in the studies by Nishikawa et al. (2010) in Japan and Roelofs et al. (2006) in Holland.

It is worth noting that this difference of gender is clearer when the results concerning aggressiveness are compared. In the comparison of results concerning delinquency, rejection on the part of caregivers seems to marginally affect the levels of aggressiveness among boys. Why were externalizing problems predicted for boys by attachment, while aggressiveness among girls was predicted in the case of parental practices?

This is an intriguing question that some researchers have already attempted to answer. Nishikawa et al. (2010) suggest that girls are more sensitive than boys to negative parental practices or that fathers and mothers are more sensitive to the behavioral problems of their daughters than those of their sons. Boys, on the other hand, are more vulnerable and would have more difficulty obtaining psychological autonomy, especially from their mothers.

Why is it that the difficulty of boys in developing secure bonds with their mothers would manifest in the form of aggressiveness and antisocial behavior? An initial argument would be that the boys' biological predisposition is to be aggressive (Keenan \& Shaw, 1997), coupled with a more aggressive style of interaction (Prinzie et al., 2006). That is, in the face of a perception of the mother's low responsiveness and support, boys would have a "natural" tendency to exhibit externalizing problems. Because behaviors of an aggressive nature are more common among boys, they are more tolerated by caregivers, and would not necessarily lead to parental 
rejection or exaggerated attempts to control them, which could explain the lack of association with parental practices.

On the other hand, paternal attachment was the only predictor of two internalizing problems for boys, but not for girls. Different researchers have shown the importance of paternal attachment in the trajectory that leads children to present internalizing problems, especially boys (Desjardins \& Leadbeater, 2011; Liu, 2008; Roelofs et al., 2006). It is possible that specifically in this age range (end of childhood and beginning of adolescence), the fathers assume a prominent role in the consolidation of the boy's personality. According to Roelofs et al. (2006), attachment in relation to the father may work for boys as a preventive factor against anxiety/depression. Therefore, we infer that the perceptions from the boys' perspective - that fathers are unresponsive, unavailable and unsupportive - negatively affect the boys' self-esteem and their sense of security, consequently leading them to become isolated from their social group and to feel anxious and depressive.

Internalizing problems among girls seem to be conditioned to different factors, depending on the problem at hand. For example, we observe that there is only one tendency of association between maternal attachment and social withdrawal in this group, while anxiety/depression were clearly predicted by low behavioral control and high psychological control, a result also observed in other studies (Finkenauer et al., 2005; Muris et al., 2003; Roelofs et al., 2006). In this study, however, not only the level of psychological control, but also a low level of behavioral control, provides unique contributions to explaining anxiety/depression in girls. That is, signs of anxiety/depression were associated with difficulties, both in terms of establishing clear rules of discipline and demanding socially appropriate behaviors, in addition to a lack of parental supervision. These results integrate an important dimension of parental practices to be considered in the investigation of predictors of anxiety and depression during childhood.

\section{Conclusion}

This study corroborates the rationale that boys and girls not only tend to present differences in regard to the expression of behavioral problems, but also in regard to the processes involved in this expression. Understanding the specificities of gender in the relations of attachment, as well as the dynamics of parental practices and their impact on the manifestation of behavioral problems favors and supports the proposition of more operational and efficient intervention strategies directed to children and their families.

There are, however, some limitations that are worth mentioning. Firstly, mothers were the majority of the caregivers participating in this study; hence, a maternal perspective was probably predominant. For this reason, the possibility of collating the effect of paternal and maternal practices on the children's behavioral problems was reduced. It is important to note that fathers and mothers tend to show little agreement in regard to their children's behavioral problems (Borsa \& Nunes, 2008) and also in regard to the way children are raised
(Bolsoni-Silva \& Loureiro, 2011). One recent study reported that this disagreement was statistically greater in the groups composed of children with externalizing and internalizing difficulties, when compared to groups with children that presented no behavioral problems (Bolsoni-Silva \& Loureiro, 2011). Therefore, future studies could, in addition, investigate the specific effects of maternal and parental practices, and verify disagreement among parents in relation to their children's behaviors and whether the rearing practices employed would negatively affect the children's behavior. It would be important and provide clarity if future research could also include the perceptions of children in relation to parental practices in the analysis. The investigation of these practices from different perspectives (that of parents and children), undoubtedly, would bring a significant and rich contribution to the clarification of this phenomenon of externalizing and internalizing problems.

It is understood that when a study addresses development, models of predictive analysis would be more appropriate when there are longitudinal data because they enable researchers to capture the effects of explanatory variables on the criterion variable over time. Therefore, longitudinal analyses are being conducted by this group to fill this gap.

Finally, for the children who are in late childhood and preadolescent stages, as is the case of those addressed in this study, their development and social adaptation are influenced by an important social group - their peers. Hence, in future studies, data on the quality of children peer relationships (e.g. attachment and friendships) needs to be examined in terms of the relevance of the role played in the process of child socialization.

\section{References}

Achenbach, T. M. (1991). Manual for Child Behavior Checklist 4-18, and 1991 profile. Burlington,VT: University of Vermont/Department of Psychiatry.

Achenbach, T. M., \& Edelbrock, C. S. (1978). The classification of child psychopathology: A review and analysis of empirical efforts. Psychological Bulletin, 85(6), 1275-1301. doi:10.1037/0033-2909.85.6.1275

Bandeira, M., Rocha, S. S., Souza, T. M. P., Del Prette, Z. A. P., \& Del Prette, A. (2006). Comportamentos problemáticos em estudantes do ensino fundamental: Características da ocorrência e relação com habilidades sociais e dificuldades de aprendizagem. Estudos de Psicologia, 11(2), 199-208. doi:10.1590/S1413-294X2006000200009

Barber, B. K. (1996). Parental psychological control: Revisiting a neglected construct. Child Development, 67(6), 32963319.doi:10.2307/1131780

Bolsoni-Silva, A. T., \& Loureiro, S. R. (2011). Práticas educativas parentais e repertório comportamental infantil: Comparando crianças diferenciadas pelo comportamento. Paidéia (Ribeirão Preto), 21(48), 61-71. doi:10.1590/S0103-863X2011000100008 
Booth-Laforce, C., Oh, W., Kim, A. H., Rubin, K. H., RoseKrasnor, L., \& Burgess, K. (2006). Attachment, selfworth, and peer-group functioning in middle childhood. Attachment \& Human Development, 8(4), 309-325. doi:10.1080/14616730601048209

Bordin, I. A. S., Mari, J. J., \& Caeiro, M. F. (1995).Validação da versão brasileira do "Child Behavior Checklist" (CBCL) (Inventário de Comportamentos da Infância e Adolescência): Dados preliminares. Revista ABP-APAL, 17(2), 55-66.

Borsa, J. C., \& Nunes, M. L. T. (2008). Concordância parental sobre problemas de comportamento infantil através do CBCL. Paidéia (Ribeirão Preto), 18(40), 317-330. doi:10.1590/S0103-863X2008000200009

Burt, S. A. (2009). Are there meaningful etiological differences within antisocial behavior? Results of a metaanalysis. Clinical Psychological Review, 29(2), 163-178. doi:10.1016/j.cpr.2008.12.004

Burt, S. A., Mikolajewski, A. J., \& Larson, C. L. (2009). Do aggression and rule-breaking have different interpersonal correlates? A study of antisocial behavior subtypes, negative affect, and hostile perceptions of others. Aggressive Behavior, 35(6), 453-461. doi:10.1002/ab.20324

Cassidy, J. (1994). Emotion regulation: Influences of attachment relationships. Monograph of the Society for Research in Child Development, 59(2-3), 228-283. doi:10.2307/1166148

Côté, S., Tremblay, R. E., Nagin, D., Zoccolillo, M., \& Vitaro, F. (2002). The development of impulsivity, fearfulness, and helpfulness during childhood: Patterns of consistency and change in the trajectories of boys and girls. Journal of Child Psychology and Psychiatry, 43(5), 609-618. doi:10.1111/1469-7610.00050

Desjardins, T. L., \& Leadbeater, B. J. (2011). Relational victimization and depressive symptoms in adolescence: Moderating effects of mother, father, and peer emotional support. Journal of Youth Adolescence, 40(5), 531-544. doi:10.1007/s10964-010-9562-1

Diener, M. L., Isabella, R. A., Behunin, M. G., \& Wong, M. S. (2008). Attachment to mothers and fathers during middle childhood: Associations with child gender, grade, and competence. Social Development, 17(1), 84-101.

Fearon, R. P., Bakermans-Kranenburg, M. J., van IJzendoorn, M. H., Lapsley, A. M., \& Roisman, G. I. (2010). The significance of insecure attachment and disorganization in the development of children's externalizing behavior: A meta-analytic study. Child Development, 81(2), 435-456. doi:10.1111/j.1467-8624.2009.01405.x

Finkenauer, C., Engels, R. C. M. E., \& Baumeister, R. F. (2005). Parenting behaviour and adolescent behavioural and emotional problems: The role of self-control. International Journal of Behavioral Development, 29(1), 58-69. doi:10.1080/01650250444000333

Graham, C. A., \& Easterbrooks, M. A. (2000). School-aged children'svulnerabilitytodepressivesymptomatology:Therole of attachment security, maternal depressive symptomatology, and economic risk. Development and Psychopathology, 12(2), 201-213. doi:10.1017/S0954579400002054
Graminha, S. S. V. (1994). Problemas emocionais/ comportamentais em uma amostra de escolares: Incidência em função do sexo e idade. Psico, 25(1), 49-74.

Karreman, A., van Tuijl, C., van Aken, M. A. G., \& Dekovíc, M. (2009). Predicting young children's externalizing problems: Interactions among effortful control, parenting, and child gender. Merrill-Palmer Quarterly, 55(2), 111-134. doi:10.1353/mpq.0.0020

Keenan, K., \& Shaw, D. (1997). Developmental and social influences on young girls' early problem behavior. Psychological Bulletin, 121(1), 95-113. doi:10.1037/0033-2909.121.1.95

Kerns, K. A., Aspelmeier, J. E., Gentzler, A. L., \& Grabill, C. M. (2001). Parent-child attachment and monitoring in middle childhood. Journal of Family Psychology, 15(1), 69-81. doi:10.1037/0893-3200.15.1.69

Kerns, K. A., Keplac, L., \& Cole, A. K. (1996). Peer relationships and preadolescents' perceptions of security in the childmother relationship. Developmental Psychology, 32(3), 457466. doi:10.1037/0012-1649.32.3.457

Laird, R. D., Marrero, M. D., \& Sentse, M. (2010). Revisiting parental monitoring: Evidence that parental solicitation can be effective when needed most. Journal of Youth and Adolescence, 39(12), 1431-1441. doi:10.1007/s10964-009-9453-5

Lieberman, M., Doyle, A.-B., \& Markiewicz, D. (1999). Developmental patterns in security of attachment to mother and father in late childhood and early adolescence: Associations with peer relations. Child Development, 70(1), 202-213. doi:10.1111/1467-8624.00015

Liu, Y.-L. (2008). An examination of three models of the relationships between parental attachments and adolescents' social functioning and depressive symptoms. Journal of Youth and Adolescence, 37(8), 941-952. doi:10.1007/s10964-006-9147-1

Marturano, E. M., Toller, G. P., \& Elias, L. C. S. (2005). Gênero, adversidade e problemas sócio-emocionais associados à queixa escolar. Estudos de Psicologia (Campinas), 22(4), 371-380. doi:10.1590/S0103-166X2005000400005

Moffitt, T. E., \& Caspi, A. (2001). Childhood predictors differentiate life-course persistent and adolescencelimited antisocial pathways among males and females. Development and Psychopathology, 13(2), 355-375. doi:10.1017/S0954579401002097

Muris, P., Meesters, C., \& van den Berg, S. (2003). Internalizing and externalizing problems as correlates of self-reported attachment style and perceived parental rearing in normal adolescents. Journal of Child and Family Studies, 12(2), 171-183. doi:10.1023/A:1022858715598

Nishikawa, S., Sundbom, E., \& Hägglöf, B. (2010). Influence of perceived parental rearing on adolescent self-concept and internalizing and externalizing problems in Japan. Journal of Child and Family Studies, 19(1), 57-66. doi:10.1007/s10826-009-9281-y 
Prinzie, P., Onghena, P., \& Hellinckx,W. (2006). A cohortsequential multivariate latent growth curve analysis of normative $\mathrm{CBCL}$ aggressive and delinquent problem behavior: Associations with harsh discipline and gender. International Journal of Behavioral Development, 30(5), 444-459. doi:10.1177/0165025406071901

Rickel, A. U., \& Biasatti, L. L. (1982). Modification of the block child rearing practices report. Journal of Clinical Psychology, 38(1), 129-134. doi:10.1002/1097-4679(198201)38:1<129::AIDJCLP2270380120>3.0.CO;2-3

Roelofs, J., Meesters, C., Ter Huurne, M., Bamelis, L., \& Muris, P. (2006). On the links between attachment style, parental rearing behaviors, and internalizing and externalizing problemsinnon-clinicalchildren.JournalofChildandFamily Studies, 15(3), 331-344. doi:10.1007/s10826-006-9025-1

Rohner, R. P., \& Britner, P. A. (2002). Worldwide mental health correlates of parental acceptance-rejection: Review of crosscultural and intracultural evidence. Cross-Cultural Research: The Journal of Comparative Social Science, 36(1), 16-47. doi:10.1177/106939702129146316

Rubin, K. H., Coplan, R. J., \& Bowker, J. C. (2009). Social withdrawal in childhood. Annual Review of Psychology, 60, 141-171. doi:10.1146/annurev.psych.60.110707.163642

Saud, L. F., \& Tonelotto, J. M. F. (2005). Comportamento social na escola: Diferenças entre gênero e séries. Psicologia Escolar e Educacional, 9(1), 47-57. doi:10.1590/S1413-85572005000100005

Teixeira, M. A. P., Oliveira, A. M., \& Wottrich, S. H. (2006). Escalas de práticas parentais (EPP): Avaliando dimensões de práticas parentais em relação a adolescentes. Psicologia: Reflexão e Crítica, 19(3), 433-441. doi:10.1590/S0102-79722006000300012

Van Brakel, A. M. L., Muris, P., Bogels, S. M., \& Thomassen, C. (2006). A multifactorial model for the etiology of anxiety in non-clinical adolescents: Main and interactive effects of behavioral inhibition, attachment, and parental rearing. Journal of Child and Family Studies, 15(5), 569-579.

Sandra Adriana Neves Nunes is a Professor of the Faculdade de Ilhéus.

Ana Maria Xavier Faraco is a Voluntary Professor of the Universidade Federal de Santa Catarina.

Mauro Luis Vieira is an Associate Professor of the Universidade Federal de Santa Catarina.

Received: Jul. $4^{\text {th }} 2012$

$1^{\text {st }}$ Revision: Nov. $5^{\text {th }} 2012$

Approved: Dec. $3^{\text {rd }} 2012$

How to cite this article:

Nunes, S. A. N., Faraco, A. M. X., \& Vieira, M. L. (2013). Attachment and parental practices as predictors of behavioral disorders in boys and girls. Paidéia (Ribeirão Preto), 23(56), 369-377. doi:10.1590/1982-43272356201311 


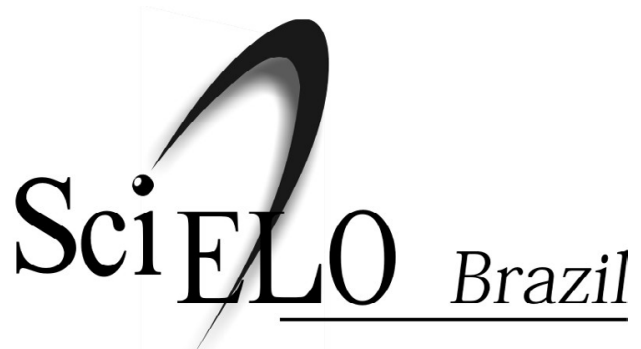

The SciELO interface provides easy access to the tables of content and to the full-text articles.

The SciELO interface also provides the retrieval of articles by the author's name, the words from title, abstract and descriptors, in addition to providing bibliometric indicators and consultation indicators.

The articles are enriched with connections to the LILACS, MEDLINE and PubMed databases.

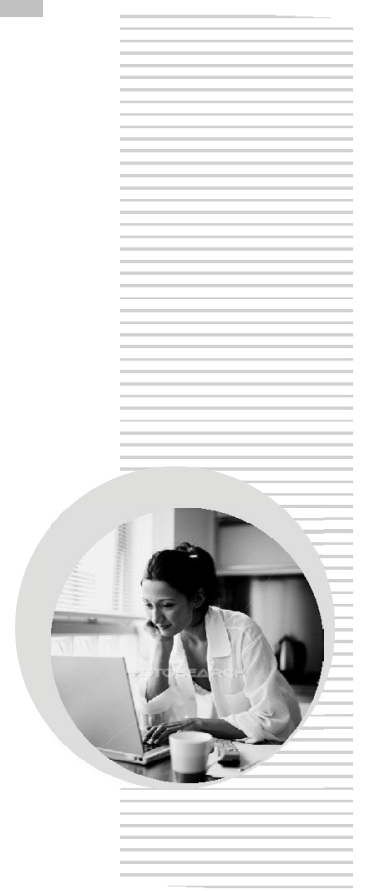

Paidéia (Ribeirão Preto) is a part of SciELO Brazil:

\section{www.scielo.br/paideia}

The SciELO interface provides access to a network of SciELO websites, gathering the major scientific journals of Latin America, Caribbean, Spain, Portugal and South Africa:

\section{www.scielo.org}

The electronic library is a project developed by the São Paulo Research Fundation (FAPESP), in partnership with the Latin American and Caribbean Center on Health Sciences Information (BIREME) and the National Council for Scientific and Technological Development (CNPq). 